\title{
REGULIUOTO UPELIO SAVAIMINIO APSIVALYMO EFEKTYVUMO VERTINIMAS
}

\author{
Laima MAROZAITE் ${ }^{1}$, Valentinas ŠAULYS ${ }^{2}$ \\ Vilniaus Gedimino technikos universitetas, Vilnius, Lietuva \\ El.paštas: ${ }^{1}$ laimamarozaitėgmail.com; ${ }^{2}$ valentinas@vgtu.lt
}

\begin{abstract}
Santrauka. Straipsnyje nagrinėjami veiksniai, darantys įtaką upių savaiminio apsivalymo procesams nuo biogeninių medžiagų, kai upės ruožai yra reguliuoti ir nereguliuoti. Savaiminio apsivalymo procesams vertinti ir lyginti buvo pasirinkti vienodo ilgio reguliuotas ir nereguliuotas upès ruožai. Beveik užtikrintai galime teigti, kad nereguliuotame ruože upelis nuo biogeninių medžiagų apsivalo geriau. Nitratų savaiminio apsivalymo koeficientas $\alpha$ nereguliuotame ruože lygus 0,42 , o reguliuotame 0,106 . Fosfatų savaiminio apsivalymo koeficientas $\alpha$ nereguliuotame ruože lygus 0,286 , o reguliuotame $-0,22$.
\end{abstract}

Reikšminiai žodžiai: nitratai, fosfatai, reguliuoti upeliai, apsivalymo efektyvumas.

\section{Ivadas}

Tekantis upių vanduo ekologiniu požiūriu yra kur kas pranašesnis už stovintị vandenị: besimaišanti vandens tẻkmė mažiau užteršta biogeninėmis medžiagomis, vanduo geriau aprūpinamas deguonimi, spartesni apsivalymo procesai (Vaikasas 2007). Tačiau, kai upé patiria dvigubą (vagos ištiesinimas ir nuotekų išleidimas) neigiamą poveiki, atkurti geros vandens būklès sąlygas yra ypač sudètinga. Sausmečio laikotarpiu dèl mažų upelių debitų ir minimalaus praskiedimo drenažiniais vandenimis šios galimybės dar sumažèja. Reguliuoti upeliai savo hidromorfologinèmis, cheminėmis ir biologinèmis savybėmis labiau primena melioracinius griovius, o ne natūralias upes (Lysovienè 2013).

Savaiminio upių vagų atsistatymo procesas labai priklauso nuo upès vagos nuolydžio, substrato, pakrantès augmenijos, medžiu šakų ir panašios kilmès kliūčių, stabdančiu vandens tèkmę ir kitaip sąlygojančiu atsistatymo greitị bei efektyvumą. Didesnio nuolydžio ištiesintos vagos upès (arba jei jos teka miškingomis vietovėmis) turi didesnę savaiminio atsistatymo galimybę nei mažo (mažesnio kaip $1,5 \mathrm{~m} / \mathrm{km}$ ) nuolydžio ištiesintos vagos upès, kurių natūrali pakrančių augmenija sunaikinta. Stovinčiame vandenyje bei mažo pratakumo vandens telkiniuose savaiminio apsivalymo procesai vyksta kur kas lèčiau, nei tekančio vandens ekosistemose (LR Aplinkos ministro... 2010).

Viena iš upių vandens kokybès problemų yra užterštumas maisto ir organinėmis medžiagomis. Maisto medžiagu kieki upiu vandenyje rodo bendrojo azoto ir fosforo koncentracijos (Ignatavičius et al. 2012).
Dèl žemès ūkio veiklos į upę gali patekti daugiau maistinių medžiagų, bet jų kiekius yra sunku prognozuoti (Jordan et al. 1997). Biogenų perteklius vandens telkinyje sukelia natūraliomis sąlygomis nebūdingą pernelyg spartų augalų ir kitų organizmų vystymąsi. Tai savo ruožtu lemia vandens masès fizinių, cheminių savybiu bei biotopu kaitą, skatina vandens telkinių uždumblèjimą ir rekreacinių išteklių sumažèjimą (Taminskas et al. 2006). Norint ivertinti žemès naudojimo poveiki, reikia atlikti tyrimus kiekviename upelio baseine (Gaigalis et al. 2006). Kyllmar su bendraautoriais, atlikdami tyrimus upių baseinuose, pastebėjo, kad nitratų kiekis sumažèjo, kai laukai buvo mažiau tręšiami organinèmis trašsomis ir buvo sumažinti sejjamų maisto kultūrų plotai (Kyllmar et al. 2006).

Azotas $(\mathrm{N})$ ir Fosforas $(\mathrm{P})$ į upę patenka iš natūralių bei antropogeninių šaltinių. Azotas gali patekti iš atmosferos, nuoteku, kanalizacijos, septikų ir žemès ūkio trą̌̌u. Fosforas patenka iš dirvožemio, žemès ūkio vietoviu ir buitiniu nuoteku, išsiskiria kaip vandens organizmų veiklos skilimo produktas (Allan 1994).

Nors azotas yra pagrindinis augalų mitybos šaltinis ir vienas labiausiai paplitusių gamtoje elementų, tačiau jo perteklius kenkia gamtai. Pavojingiausia aplinkai azoto forma yra nitratai $\left(\mathrm{NO}_{3}^{-}\right)$, kuriu, skirtingai negu amonio ( $\mathrm{NH}_{4}^{+}$), neisisavina dirvožemis ir prasčiau paima augalai, todèl jie migruoja biosferoje. Apie $90-98 \%$ azoto iš dirvožemio išplaunama kaip nitratai. Be to, dalis nitratų virsta kenksmingais nitritais $\left(\mathrm{NO}_{2}^{-}\right)$. Didelę ịtaką cheminių 
elementų ir junginių migracijai daro krituliai, o vandens infiltracijos procesų dirvožemiuose intensyvumui - hidroterminis režimas ir dirvožemio granuliometrinè sudetis. Azoto išplovimas priklauso nuo žemès dirbimo, kalkinimo, tręšimo, augalų rūšies, dirvožemio genezès ir granuliometrinès sudèties, prasisunkusio vandens kiekio, dirvožemio azotingumo, klimatinių sąlygų, dirvos užimtumo augalais (Adomaitis et al. 2004).

Nitratų koncentracija vandenyje padidèja rudens liūčių metu, kai plaunamos dirvos, kurios yra prisotintos nitratų (Velasco et al. 2004).

Tyrimo tikslas - įvertinti taršos veikiamų Durbinio upelio reguliuotų ir nereguliuotų ruožų savaiminị apsivalymą nuo biogeninių medžiagų atsižvelgiant i gamtines ir antropogenines sąlygas.

\section{Tyrimo objektas ir metodika}

Pagal ilgiausią reguliuotą upès ruožą $(1,8 \mathrm{~km})$ buvo pasirinktas to paties ilgio nereguliuotas upès ruožas. Vandens méginiai buvo imami reguliuoto upès ruožo pradžioje (1 vieta), reguliuoto upès ruožo pabaigoje - nereguliuoto ruožo pradžioje (2 vieta) ir nereguliuoto ruožo pabaigoje (3 vieta). Tyrimo vietú išsidèstymas parodytas 1 pav.

Tiriamojo upelio bendros charakteristikos: ilgis 9,1 km; vyresnis vandentakis - Mastupis; baseino plotas $15,5 \mathrm{~km}^{2}$; intakų nèra. Durbinio versmès yra Užgirių kaime. Nuo versmių iki 7,8 km, nuo 7,4 iki 7,2 km ir nuo 4,8 iki $3,0 \mathrm{~km}$ upelis yra reguliuotas (Gailiušis et al. 2001).

Tiriant upès užterštumą buvo atliekami natūriniai matavimai. Tiriamos upès vanduo buvo imamas kartą per mènesi nuo 2013 lapkričio mèn. iki 2014 lapkri-

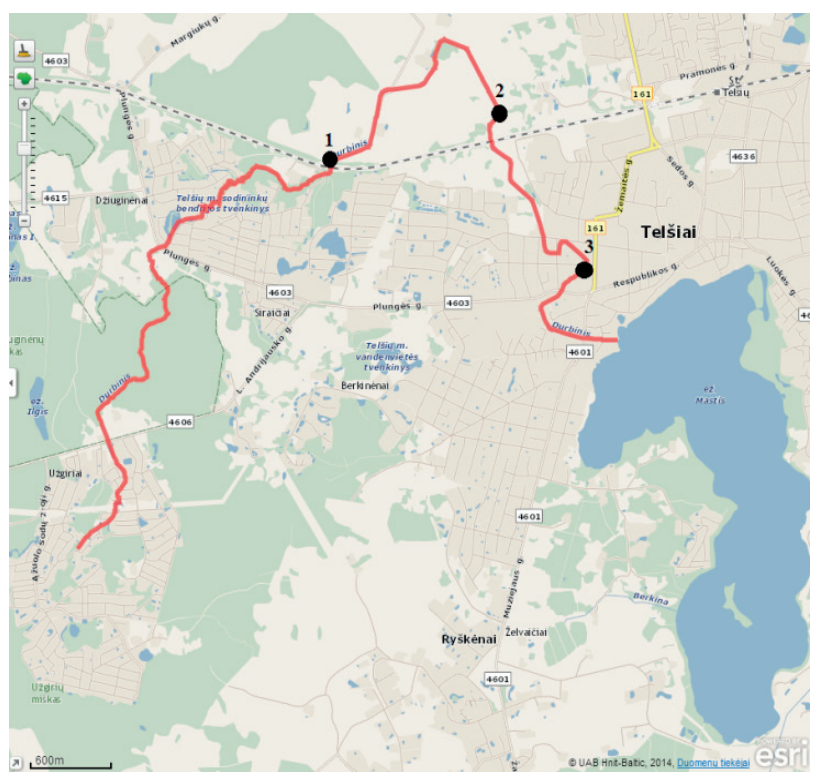

1 pav. Mèginių ėmimo vietos (šaltinis: http://www.maps.lt)

Fig. 1. The sampling points (source: http://www.maps.lt) čio mèn. Vandens mėginiai buvo imti pagal LST EN ISO 5667-1:2007 standarte nustatytus reikalavimus, tvarkomi ir konservuojami pagal LST EN ISO 5667-3:2006 standartą. Mèginių tyrimai atlikti Vilniaus Gedimino technikos universiteto Hidraulikos katedros mokomojoje laboratorijoje su „HANNA Instruments“ multiparametriniu fotometru HI 83205. Šiuo prietaisu nustatytos nitratų ir fosfatų koncentracijos. Prietaisas veikia taip: specialiomis lempomis sukuriamas šviesos spindulys nukreipiamas $i$ kiuvetèje esanti mėgini. Taikant spektrofotometrinę analizę, matuojama šviesos absorbcija. Tiriamosios medžiagos tirpalo spalvos intensyvumas lyginamas su standartinio tirpalo spalvos intensyvumu. Ši analizè yra labai tiksli ir pakankamai sparti.

Upių ekologinè būklè vertinama pagal fizikinius-cheminius kokybès elementus - bendrus duomenis apibūdinančius rodiklius: nitratų azotą $\left(\mathrm{NO}_{3}-\mathrm{N}\right)$, fosfatų fosforą $\left(\mathrm{PO}_{4}-\mathrm{P}\right)$. Didžiausią leistiną jonų koncentraciją, pateiktą viena ar kita forma, galima transformuoti i kitą formą, taikant pastovius daugiklius:

$$
\begin{aligned}
& \text { - nitratams: 4,427 }\left(\mathrm{NO}_{3}-\mathrm{N}\right)=\mathrm{NO}_{3} \text {; } \\
& \text { - fosfatams: 3,066 }\left(\mathrm{PO}_{4}-\mathrm{P}\right)=\mathrm{PO}_{4} \text { (Šaulys 2007). }
\end{aligned}
$$

Pagal kiekvieno rodiklio vidutinę metų vertę vandens telkinys priskiriamas vienai iš penkių ekologinès būklès klasių. Gautos vidutinès vienerių metų rodiklių vertès palygintos su 1 lentelèje pateiktais Upių ekologinès būklès klasès pagal fizinių-cheminių kokybès elementų rodikliais (LR Aplinkos ministro... 2010).

1 lentelè. Upių ekologinès būklès klasės pagal fizinių-cheminių kokybės elementų rodiklius (LR Aplinkos ministro... 2010) Table 1. River ecological status of natural-chemical elements indicators (LR Aplinkos ministro... 2010)

\begin{tabular}{|c|c|c|l|l|l|}
\hline \multirow{2}{*}{ Rodiklis } & \multicolumn{5}{|c|}{$\begin{array}{c}\text { Upių ekologinės būklès klasių kriterijai } \\
\text { pagal fizikiniu-cheminiu kokybès elementų } \\
\text { rodikliu vertes }\end{array}$} \\
\cline { 2 - 6 } & $\begin{array}{c}\text { Labai } \\
\text { gera }\end{array}$ & Gera & Vidutinè & Bloga & $\begin{array}{c}\text { Labai } \\
\text { bloga }\end{array}$ \\
\hline $\mathrm{NO}_{3}-\mathrm{N}, \mathrm{mg} / l$ & $<1,30$ & $\begin{array}{l}1,30- \\
2,30\end{array}$ & $\begin{array}{l}2,31- \\
4,50\end{array}$ & $\begin{array}{l}4,51- \\
10,00\end{array}$ & $>10,00$ \\
\hline $\mathrm{PO}_{4}-\mathrm{P}, \mathrm{mg} / l$ & $<0,050$ & $\begin{array}{l}0,050- \\
0,090\end{array}$ & $\begin{array}{l}0,091- \\
0,180\end{array}$ & $\begin{array}{l}0,181- \\
0,400\end{array}$ & $>0,400$ \\
\hline
\end{tabular}

Upės savaiminio apsivalymo nuo biogeninių medžiagų procesui ivvertinti buvo panaudota supaprastinta formulè:

$$
\alpha=\ln \left(\frac{C_{O}}{C_{L}}\right) / L,
$$

čia: $C_{O}-$ cheminès medžiagos koncentracija upès skaičiuojamo ruožo pradžioje $\mathrm{mg}^{-1} ; C_{L}$ - cheminès medžiagos koncentracija upès skaičiuojamo ruožo pabaigoje $\mathrm{mg} \mathrm{l}^{-1} ; L$ - upés ruožo ilgis $\mathrm{km} ; \alpha$ - upès valymosi koeficientas $\mathrm{km}^{-1}$. 
Išsklaidytosios taršos poveikis baseinui nustatinèjamas pagal upès baseino žemès plotu naudojimo paskirti. Tam tikslui išnagrinètas Durbinio upès baseinas $\left(15,5 \mathrm{~km}^{2}\right)$. Upès savaiminiam apsivalymui įtakos turinčios baseino fizinès-geografinès charakteristikos vertinamos pagal žemès plotu panaudojimą baseine, nuogulų ir žemès naudmenu pasiskirstymą, kritulių infiltraciją ir garavimą. Tiriant upés baseiną, naudotas Lietuvos kosminio vaizdo žemėlapis M 1:50 000, vektorinių duomenų bazè (Lietuvos kosminio... LTDBK50000-V) ir Lietuvos reljefo kadastro duomenų elektroninis variantas (Baubinienè et al. 2002).

Apsaugos juostoms tirti buvo pasirinktos Durbinio upelio reguliuoto ir nereguliuoto ruožų atkarpos po $1,8 \mathrm{~km}$. Tiriamieji ruožai suskirstyti i 30 profilių (15 profilių reguliuotame ir 15 profilių nereguliuotame upès ruožuose). Atstumas tarp profilių - 50 metrų, o tiriamojo ruožo ilgis -10 metru.

Kiekviename tirtajame ruože buvo nustatytas ten augusios sumedejjusios augalijos išplitimas pagal atskiru rūšiu, bendrijų bei jų visumos kiekybinius ir kokybinius radimvietėse požymius:

- rūšių skaičių;

- dažnį - sumedejjusios augalijos paplitimo dažnis buvo nustatytas kaip vagos šlaitų ar jų dalių (pakrantès apsaugos juostos; viršutinès, vidurinès dalies bei papėdès), kuriose buvo rasta rūšis, t. y. radviečių, santykis su visų tirtų ruožų skaičiumi, \%.

\section{Rezultatai ir jų analizè}

Išnagrinèjus baseine esančiu žemès naudmenu pasiskirstymą, nustatyta, kad didžiają baseino dali užima miškai $42,13 \%$ ir ariamos žemés plotai - 35,29\%. Teritoriniu požiūriu urbanizuotos teritorijos užima $21,23 \%$ baseino teritorijos, ir tik 1,35 \% užima ežerai ir tvenkiniai. Didžioji dalis dirbamų laukų ribojasi su upe. Todèl galima teigti, kad dirbami laukai yra išsklaidytosios taršos šaltinis, darantis didžiausią itaką Durbinio upès vandens kokybei, nes, tręšiant dirbamus laukus, vandenyje gausẻja azoto ir fosforo junginiu.

Ivertinus litologiju pasiskirstymą baseine, matyti, kad pagrindine baseino nuogula yra smèlis, kuris patenka beveik i visus arealus. Procentais vyraujančių nuogulų pasiskirstymas baseine: smèlis $-44,45 \%$, priesmèlis ant priemolio $-22,01 \%$, priemolis $-21,09 \%$, molis $-12,45 \%$.

Ivertinus vandens išteklius baseine, gauti rezultatai, kad vienos liūties metu ir esant vidutiniam kritulių kiekiui Durbinio upès baseine krituliai nesusigeria iš urbanizuotu teritoriju, nes vyrauja mažai laidūs paviršiai. Visose kitose teritorijose krituliai issigeria.

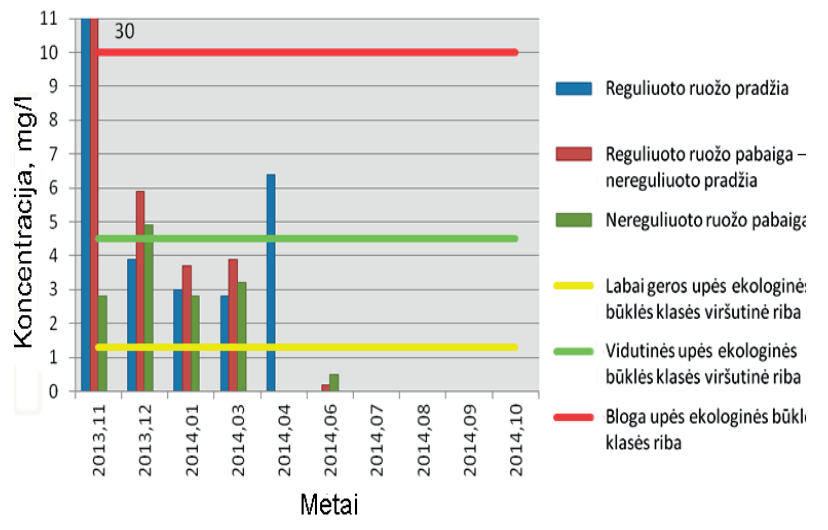

2 pav. Nitratu koncentracija Durbinio upelyje 2013-2014 metais

Fig 2. Nitrate concentrations of Durbinis stream in the years 2013-2014

Pagal 2 pav. matyti, kaip kinta nitratų koncentracija tiriamuose upes ruožuose. Didžiausia nitratų koncentracija nustatyta $2013 \mathrm{~m}$. lapkričio - $2014 \mathrm{~m}$. balandžio mèn. (nuo $6,4 \mathrm{mg} / \mathrm{l} \mathrm{iki} 30 \mathrm{mg} / l$ ), o mažiausia - $2014 \mathrm{~m}$. birželio $2014 \mathrm{~m}$. spalio mèn. (nuo $0,0 \mathrm{mg} / \mathrm{l}$ iki $0,5 \mathrm{mg} / l$ ). Nitratu koncentracijos padidejjimą vandenyje lemia išsklaidytoji tarša iš dirbamų laukų, itakos turi ir buitine tarša.

2013 m. lapkričio mèn. reguliuoto ruožo pradžioje - reguliuoto ruožo pabaigoje nitratų koncentracija nepasikeitè, o reguliuoto ruožo pabaigoje - nereguliuoto ruožo pradžioje nitratų koncentracija sumažèjo 10,7 karto. Gruodžio mèn. reguliuotame ruože nitratų koncentracija padidèjo 1,5 karto, o nereguliuotame ruože sumažèjo 1,2 karto. Sausio mèn. reguliuotame ruože nitratų koncentracija padidejjo 1,2 karto, o nereguliuotame ruože sumažèjo 1,3 karto. Kovo mèn. reguliuotame ruože nitratų koncentracija padidèjo 1,4 karto, o nereguliuotame ruože sumažèjo 1,2 karto. Balandžio mèn. nuo pradinio reguliuoto ruožo pradžios taško iki nereguliuoto ruožo pabaigos upe visiškai apsivalè. Kitais mėnesiais nitratų koncentracijos lygios $0 \mathrm{mg} / \mathrm{l}$. Galime pastebèti, kad upè reguliuotame ruože apsivalo nežymiai arba patekusių nitratų koncentracija dar padidejja, o nereguliuotame ruože apsivalo geriau.

Vertinant upių ekologinès būklès klasę pagal fiziniųcheminių kokybès elementų rodiklius, iš 2 pav. matyti, kad pagal nitratų koncentracijas labai gera upès ekologinè būklès klasė nustatyta 2014 m. birželio - spalio mèn., vidutinè klasė buvo $2014 \mathrm{~m}$. sausio ir kovo mèn., o $2013 \mathrm{~m}$. lapkričio mèn. nustatyta nitratų koncentracija 3 kartus viršijo leistinas normas ir buvo priskirta labai blogos upès ekologinès būklès klasei.

3 pav. pateikta fosfatu koncentracijos kaita tyrimu laikotarpiu, kuriame sezoniškumas nèra pastebimas, nes fosfatu koncentracijos visais mènesiais buvo labai didelès. Mažiausia fosfatų koncentracija, nustatyta $2013 \mathrm{~m}$. 


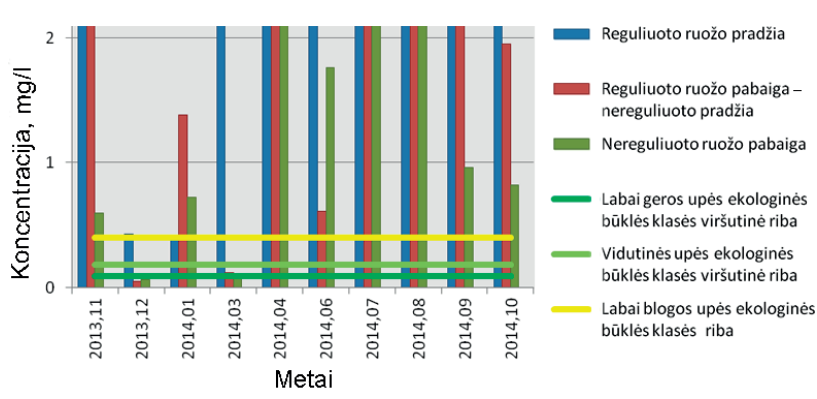

3 pav. Fosfatu koncentracija Durbinio upelyje 2013-2014 metais

Fig 3. Phosphate concentrations of Durbinis stream in the years 2013-2014

gruodžio mèn., yra $0,05 \mathrm{mg} / l$ (reguliuoto ruožo pabaigoje - nereguliuoto ruožo pradžioje). Didžiausia nustatyta koncentracija, 2,5 mg/l, buvo $2013 \mathrm{~m}$. lapkričio mèn., bei 2014 m. sausio - lapkričio mèn. 2013 m. lapkričio mèn. fosfatu koncentracija reguliuotame ruože nepasikeité, o nereguliuotame ruože sumažėjo 4,2 karto. Gruodžio mèn. fosfatų koncentracija reguliuotame ruože sumažějo 8,6 karto, o nereguliuotame ruože padidejjo 1,2 karto. Sausio mèn. fosfatų koncentracija reguliuotame ruože padidejo 3,5 karto, o nereguliuotame ruože sumažějo 1,9 karto. Kovo mèn. fosfatų koncentracija reguliuotame ruože sumažèjo 21 kartą, o nereguliuotame ruože sumažèjo 1,7 karto. Balandžio mèn. fosfatų koncentracija nežymi. Birželio mèn. fosfatų koncentracija reguliuotame ruože sumažèjo 4,1 karto, o nereguliuotame ruože padidèjo 2,9 karto. Nuo $2014 \mathrm{~m}$. liepos iki spalio mèn. fosfatų koncentracija kaita upès ruožuose kito nežymiai arba išvis nekito.

Vertinant upių ekologinès būklès klasę pagal fizinių-cheminių kokybès elementu rodiklius iš 4-5 pav. matyti, kad pagal fosfatų koncentracijas labai geros upès ekologinè būklès klasė nustatyta $2013 \mathrm{~m}$. gruodžio 2014 m. kovo mèn. nereguliuotame upès ruože, o kitais mènesiais fosfatų koncentracija viršijo leistinas normas ir buvo priskirta labai blogos upès ekologinès būklès klasei. Galima daryti prielaida, kad upès savaiminio apsivalymo nuo fosfatų procesui daro ittaką atstumas nuo taršos šaltinio. Durbinio upès ištakos yra sodų bendrijoje, kuri neprijungta prie centralizuotu miesto tinklų.

Vertinant, kokią itaką upès debitas turi nitratų ir fosfatų koncentracijos kaitai vandenyje, buvo nustatyti hidrologiniai parametrai. Vandens gylis, upès plotis ir vandens tekejjimo greitis išmatuoti žiemą, vasarą ir rudeni. Pagal gautus duomenis buvo braižomas matuojamo taško skerspjūvis ir apskaičiuojamas pratekantis debitas.

Nagrinejjamu laikotarpiu upès plotis svyravo nuo 2,2 m iki 0,44 m, gylis svyravo nuo 0,24 iki $0,05 \mathrm{~m}, \mathrm{o}$ gautas debitas svyruoja nuo $0,072 \mathrm{~m}^{3} / \mathrm{s}$ iki $0,0024 \mathrm{~m}^{3} / \mathrm{s}$.

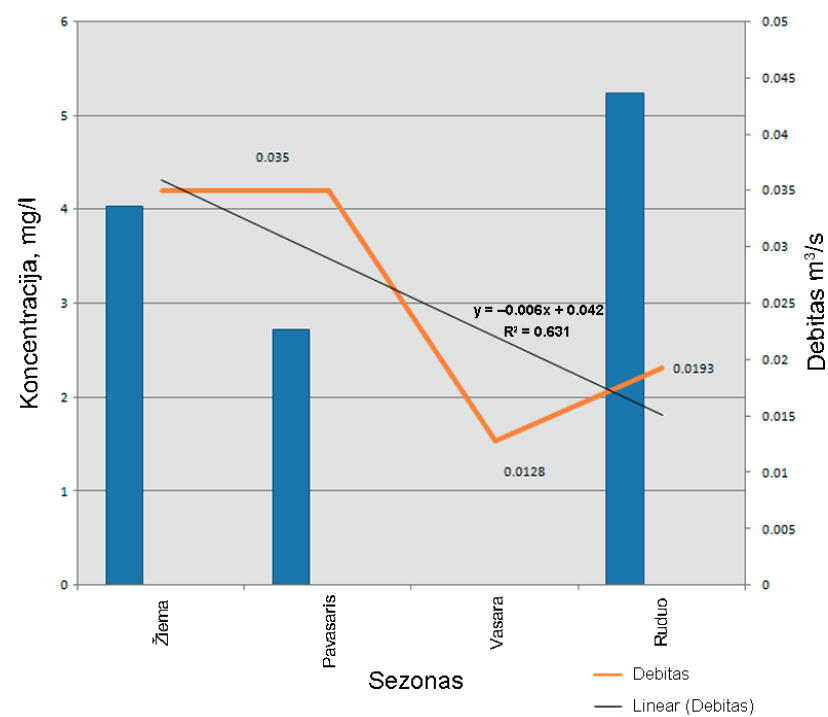

4 pav. Vidutinė sezoninė nitratų koncentracija ir upès debitas

Fig. 4. Seasonal average nitrate concentrations and river

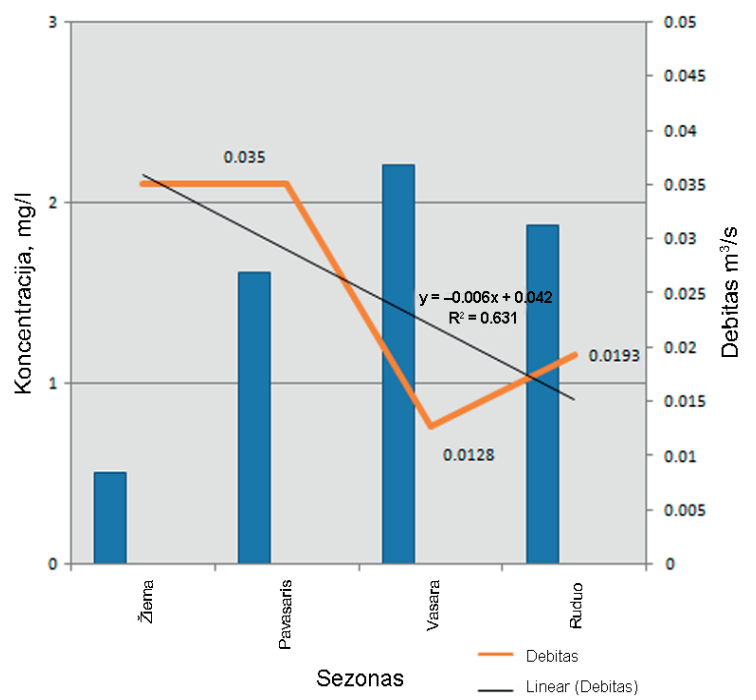

5 pav. Vidutinè sezoninė fosfatų koncentracija ir upès debitas

Fig. 5. Seasonal average phosphate concentrations and river flow

Tolimesnè analizė buvo atliekama nagrinėjant atskirus sezonus. Žiemą ir pavasarị esant didžiausiam upès debitui $\left(0,035 \mathrm{~m}^{3} / \mathrm{s}\right)$ nitratų ir fosfatų koncentracija yra mažesnè lyginant su vasarą ir rudeni gauta koncentracija. Taip yra todèl, kad didžiausias debitas būna pavasarị, kai upé maitinama sniego tirpsmo, kritulių vandeniu. Šiuo atveju matyti, kad ir žiemą buvo didesnis debitas, nes upe buvo užšalusi tik vasario mèn., gruodžio mèn. buvo daug sniego. Debito determinacijos koeficientas $\mathrm{R}=0,63$.

Vasarą ir rudeni gausiau tręšiami dirbami laukai. Didesnis kiekis nitratų teršalų išplaunamas į upes, o vasaros metu dèl nuosèkio upès vanduo mažiau praskiedžiamas. Tas pat tinka ir fosfatams. Iš namų ūkių, dirvožemio ar žemès 
2 lentelè. Savaiminio apsivalymo koeficientai $\alpha$

Table 2. Self-purification coefficients $\alpha$

\begin{tabular}{|l|c|c|c|c|}
\hline & \multicolumn{2}{|c|}{ Nitratai } & \multicolumn{2}{c|}{ Fosfatai } \\
\hline & Reguliuotas ruožas & Nereguliuotas ruožas & Reguliuotas ruožas & Nereguliuotas ruožas \\
\hline 2013 lapkritis & 0 & 1,32 & 0 & 0,79 \\
\hline 2013 gruodis & $-0,23$ & 0,10 & 1,20 & $-0,10$ \\
\hline 2014 sausis & $-0,12$ & 0,15 & $-0,70$ & 0,36 \\
\hline 2014 kovas & $-0,18$ & 0,11 & 1,69 & 0,30 \\
\hline 2014 balandis & 0 & 0,42 & 0,05 & 0,02 \\
\hline 2014 birželis & - & - & 0,78 & $-0,59$ \\
\hline 2014 liepa & - & - & 0 & 0 \\
\hline 2014 rugpjūtis & - & - & 0 & 0 \\
\hline 2014 rugsejjis & - & - & 0,01 & 0,52 \\
\hline 2014 spalis & - & - & 0 & 0,48 \\
\hline 2014 lapkritis & - & - & 0,12 & 0,65 \\
\hline
\end{tabular}

Pastaba: kai reikšmè lygi 0, upelio ruožas neapsivalė; teršalų upelyje nenustatyta.

ūkio patekę fosfatai sunkiau pašalinami, kai upeje vanduo mažiau prasiskiedžia, t. y. vasarą, o geresnis apsivalymas pastebimas esant didesniam debitui.

2013-2014 m. žiemą gautas nitratų aritmetinis vidurkis $-4,03 \mathrm{mg} / l$, atsitiktine paklaida $-0,22$, pasikliautinasis intervalas esant $95 \%$ patikimumui yra 3,65-4,41. Pavasari gautas aritmetinis vidurkis $-2,715 \mathrm{mg} / l$, atsitiktinè paklaida $-0,15$, pasikliautinasis intervalas esant $95 \%$ patikimumui yra 2,45-2,97. Rudeni gautas aritmetinis vidurkis $-5,23 \mathrm{mg} / l$, atsitiktinè paklaida $-1,91$, pasikliautinasis intervalas esant $95 \%$ patikimumui yra 1,99-8,47.

Žiemą gautas fosfatų aritmetinis vidurkis $-0,505 \mathrm{mg} / l$, atsitiktine paklaida $-0,08$, pasikliautinasis intervalas esant $95 \%$ patikimumui yra $0,36-0,64$. Pavasari gautas aritmetinis vidurkis $-1,61 \mathrm{mg} / l$, atsitiktiné paklaida $-0,18$, pasikliautinasis intervalas esant $95 \%$ patikimumui yra $1,29-1,92$. Vasara gautas aritmetinis vidurkis $-2,21 \mathrm{mg} / \mathrm{l}$, atsitiktine paklaida $-0,09$ pasikliautinasis intervalas esant $95 \%$ patikimumui yra 2,04 - 2,36. Rudeni gautas aritmetinis vidurkis $-1,87 \mathrm{mg} / l$, atsitiktinè paklaida $-0,019$, pasikliautinasis intervalas esant $95 \%$ patikimumui yra 1,84-1,91.

Pagal gautas nitratu ir fosfatu koncentracijas buvo vertinamas savaiminio apsivalymo koeficientas ir daroma išvada, kaip upe sugeba apsivalyti nuo i ją patekusių teršalų. Upès savaiminio apsivalymo procesui vertinti buvo pasirinkti vienodo ilgio reguliuotas ir nereguliuotas upès ruožai po $1,8 \mathrm{~km}$.

Pagal apskaičiuotus savaiminio apsivalymo koeficientus matyti, kad upé geriau apsivalo nereguliuotame upès ruože. Upès vandens valymosi koeficientas didesnis, kai didesnis santykis tarp teršalų koncentracijos ruožo pradžioje ir ruožo gale. Biogeninių medžiagų savaiminio apsivalymo koeficientai pateikti 2 lentelèje.
Pagal 2 lentelę matyti, kad savaiminis apsivalymas nuo nitratų reguliuotame upés ruože visai nevyko, nes savaiminio apsivalymo koeficientas buvo neigiamas. Neigiamos savaiminio apsivalymo koeficiento reikšmès rodo, kad į upę patenka dideli nitratų teršalų kiekiai. Nereguliuoto ruožo savaiminio apsivalymo koeficientas svyravo nuo 0,1 iki 1,32. Geriausias apsivalymo koeficientas nustatytas $2013 \mathrm{~m}$. lapkričio mèn., kai upè tekèdama reguliuotu ruožu neapsivalè, o nereguliuotame ruože apsivalymo koeficientas buvo didžiausias $-1,32$.

Apskaičiuoti fosfatų savaiminio apsivalymo koeficientai parodè, kad koeficientai reguliuotame ir nereguliuotame upės ruožuose labai svyruoja. Reguliuotame upès ruože didžiausias apsivalymo koeficientas apskaičiuotas $2014 \mathrm{~m}$. kovo mèn. - 1,69. Koeficientai svyravo nuo 0,7 iki 1,69. Nereguliuotame upès ruože dididžiausias apsivalymo koeficientas apskaičiuotas $2013 \mathrm{~m}$. lapkričio mèn. - 0,79. Šiame ruože koeficientai svyravo nuo 0,59 iki 0,79 .

Siekiant, kad i upes patektų kuo mažiau teršalų, upių pakrantėse yra nustatomos apsaugos juostos. Apsaugos juostose vykdoma ūkinè veikla gali turèti tiesiogini poveiki vandens kokybei, todèl svarbu ivertinti apsaugos juostos pločius, kad būtų išlaikomi reikalaujami atstumai ir taip būtų užtikrinama, kad kuo mažiau teršalų patektų i upes.

Apskaičiavus visų tirtų ruožu pakrantès apsaugos juostų pločius, buvo gautas bendras reguliuoto upès ruožo apsaugos juostos pločio vidurkis - 5,4 m (atsitiktinè paklaida 0,84 ), o nereguliuoto ruožo $-5,62 \mathrm{~m}$ (atsitiktinè paklaida $0,66)$. Iš 30 tirtų ruožų pagal norminių aktų reikalavimus apsaugos juosta buvo išlaikyta 20 ruožų. Juostos vidutinis plotis svyravo nuo 5 iki 8,6 m.

Iš tiriamuju 30 upès apsaugos juostos ruožu, sumedejjusi augalija buvo rasta 15 ruožų. Ivertinus apsaugos juostose augančią augaliją pastebèta, kad tiek žolinè, tiek 
sumedejjusi augalija turi vienodą itaką savaiminio apsivalymo procesui nuo biogeninių medžiagų.

\section{Išvados}

1. Savaiminis upès apsivalymas nuo nitratų geriau vyksta nereguliuotame upės ruože, gauti koeficientai svyruoja nuo 0,1 iki 1,32. Nors didžiausias fosfatų apsivalymo koeficientas buvo gautas reguliuotame ruože - 1,69,vertinant visų mènesių fosfatų apsivalymo koeficientus, taip pat galima teigti, kad nereguliuotame ruože savaiminis apsivalymas nuo fosfatų vyksta geriau.

2. Didžiają baseino dali užima miškai $42,13 \%$ ir ariamos žemès plotai 35,29 \%. Prie tiriamujų upės ruožu paplitę dirbami laukai, todèl tai pagrindinis pasklidosios taršos šaltinis. Ivertinus litologijų pasiskirstymą baseine, matyti, kad pagrindinè baseino nuogula yra smèlis 44,45\%. Vienos liūties metu ir esant vidutiniam kritulių kiekiui Durbinio upès baseine krituliai nesusigeria urbanizuotose teritorijose, nes vyrauja mažai laidūs paviršiai. Visose kitose teritorijose krituliai isigeria.

3. Žiemą ir pavasari esant didžiausiam upès debitui $\left(0,035 \mathrm{~m}^{3} / \mathrm{s}\right)$ nitratų ir fosfatų koncentracija yra mažesnè lyginant su vasarą ir rudeni gautomis koncentracijomis.

4. Apskaičiavus visų tirtų ruožų pakrantès apsaugos juostų pločius buvo gautas bendras vidurkis, 5,43 m. Pastebèta, kad esant didesnei apsaugos juostai teršalų koncentracijos vandenyje mažesnès. Ivertinus apsaugos juostose augančią augaliją pastebèta, kad tiek žolinè, tiek sumedejusi augalija turi vienodą itaką savaiminio apsivalymo nuo biogeninių medžiagų procesui.

\section{Literatūra}

Adomaitis, T.; Vaišvila, Z. et al. 2004. Azoto junginių ( $\mathrm{NO}_{3}^{-}$, $\mathrm{NH}_{4}^{+}, \mathrm{NO}_{2}^{-}$) koncentracija lizimetru vandenyje skirtingai tręšiamose smèlingų priemolių dirvožemiuose, Lietuvos žemdirbystès institutas 4(88): 21-33.

Allan, J. D. 1994. Stream ecology: Structure and function of running waters. Boston: Kluwer academic publishers.

Aplinkos būklè 2012. Tik faktai. Ignatavičius, G.; Satkūnas, J.; Sinkevičius, S. et al. (Red.).

Baubinienè, A.; Bautrėnas, A.; Česnulevičius, A. (red.); Morkūnaitè, R.; Paškauskas, S.; Vekeriotienė, I.; Veteikis, D. 2002. Lietuvos reljefo kadastras. Elektroninis variantas. ISBN 9986-953-07-3. Vilnius: Geografijos institutas. 2060 p.

Gaigalis, K.; Šileika, A. S.; Smitienè, A. 2006. Azoto ir fosforo koncentracijų kaita žemès ūkio veikiamuose upeliuose, Vandens ūkio inžinerija 30(50): 44-56.

Gailiušis, B.; Jablonskis, J.; Kovalenkoviene, M. 2001. Lietuvos upés. Hidrografija ir nuotekis. Kaunas: Lietuvos energetikos institutas. $792 \mathrm{p}$.
Jordan, E. J.; Correll, D. L.; Weller, D. E. 1997. Effects of agriculture on discharges of nutrients from coastal plain water sheds of Chesapeake Bay, Journal of Environmental Quality 26(3): 836-848. http://dx.doi.org/10.2134/jeq1997.00472425002600030034x

Kyllmar, K.; Carlsson, C.; Gustafson, A.; Ulen, B.; Johnsson, H. 2006. Nutrient discharge from small agricultural catchments in Sweden: Characterisation and trends, Agriculture, Ecosystems and Environment 115(1-4): 15-26. http://dx.doi.org/10.1016/j.agee.2005.12.004

Lietuvos kosminio vaizdo žemélapio M 1:50000 skaitmeninė duomenu bazé LTDBK50000-V [interaktyvus], 2014 [žiūrèta $2014 \mathrm{~m}$. rugsèjo $5 \mathrm{~d}$.].

http://www.gis-centras.lt/gisweb/index.php?pageid=213

Lietuvos Respublikos Aplinkos ministro 2010 m. kovo 4 d. isakymas Nr. D1-178 „Dèl Aplinkos ministro 2007 m. balandžio 12 d. i̇sakymo Nr. D1-210 „Dèl paviršinių vandens telkinių ekologinès būklès vertinimo tvarkos aprašo patvirtinimo“" pakeitimo, Valstybès Žinios 2010, Nr. 29-1363.

Lietuvos Respublikos vyriausybès nutarimas 2010 m. „Dèl Lielupés upių baseino rajono valdymo plano ir priemoniu vandensaugos tikslams Lielupés upių baseino rajone pasiekti programos patvirtinimo“, Lietuvos Respublikos Aplinkos ministro $2010 \mathrm{~m}$. kovo 4 d. isakymas Nr. D1-178, Valstybès Žinios 2010, Nr. 1618.

Lysovienè, J. 2013. Tarša veikiamu vidurio Lietuvos reguliuotu upeliu savaiminis apsivalymas sausmečio laikotarpiu: daktaro disertacija. Kaunas: Aleksandro Stulginskio universitetas. $93 \mathrm{p}$.

Šaulys, V. 2007. Vandenu apsaugos politika ir teisé: mokomoji knyga. Vilnius: Technika. $151 \mathrm{p}$.

Taminskas, J.; Linkevičienè, R.; Šimanauskienè, R. 2006. Fosforo šaltiniai ir nuotèkis Žuvinto baseine, Annales Geographicae 39(1): 25-33.

Vaikasas, S. 2007. Ekologine hidraulika: mokomoji knyga. Vilnius: Technika. $211 \mathrm{p}$.

Velasco, J.; Lloret, J.; Milan, A. et al. 2006. Nutrient and particulate inputs into the Mar Menor Lagoon (Se Spain) from an intensive agricultural watershed, Water, Air and Soil Pollution 176(1): 37-56. http://dx.doi.org/10.1007/s11270-006-2859-8

\section{STREAM SELF-PURIFICATION EFFICIENCY}

\section{Marozaitė, V. Šaulys}

Summary

The article identifies factors that have influence on the processes of river self-purification from biogenic substances when the stretches of the river are regulated and unregulated. In order to assess and compare the processes of self-purification, regulated and unregulated stretches of the river of the same length were chosen. It can be showed conclusively that the river in the unregulated stretch purifies from biogenic substances better. Rate $\alpha$ of nitrates self-purification in an unregulated stretch was 0.42 and in regulated stretch it was 0.106 . Rate $\alpha$ of phosphates self-purification in an unregulated stretch was 0.286 and in regulated stretch it was 0.22 .

Keywords: nitrates, phosphates, regulated streams, self-purification. 